STUDI

FRANCESI

\section{Studi Francesi}

Rivista quadrimestrale fondata da Franco Simone

157 (LIII | I) | 2009

Varia

\title{
Jonathan Dumont, Ordre social et destin impérial dans les «Chroniques de Louis XII» de Jean d'Auton
}

\section{Filippo Fassina}

\section{(2) OpenEdition}

\section{Journals}

\section{Edizione digitale}

URL: http://journals.openedition.org/studifrancesi/8205

DOI: $10.4000 /$ studifrancesi.8205

ISSN: 2421-5856

\section{Editore}

Rosenberg \& Sellier

\section{Edizione cartacea}

Data di pubblicazione: 1 mai 2009

Paginazione: 156

ISSN: 0039-2944

\section{Notizia bibliografica digitale}

Filippo Fassina, «Jonathan Dumont, Ordre social et destin impérial dans les «Chroniques de Louis XII» de Jean d'Auton», Studi Francesi [Online], 157 (LIII | I) | 2009, online dal 30 novembre 2015, consultato il 12 janvier 2021. URL: http://journals.openedition.org/studifrancesi/8205 ; DOI: https://doi.org/10.4000/ studifrancesi.8205

Questo documento è stato generato automaticamente il 12 janvier 2021.

\section{(c)}

Studi Francesi è distribuita con Licenza Creative Commons Attribuzione - Non commerciale - Non opere derivate 4.0 Internazionale. 


\title{
Jonathan Dumont, Ordre social et destin impérial dans les «Chroniques de Louis XII» de Jean d'Auton
}

\author{
Filippo Fassina
}

\section{NOTIZIA}

JONATHAN DUMONT, Ordre social et destin impérial dans les «Chroniques de Louis XII» de Jean d'Auton, «Bibliothèque d'Humanisme et Renaissance», LXIX, 3 (2007), pp. 589-613.

1 L'A. analizza dal punto di vista storico e letterario la figura di Jean d'Auton e la sua opera, le Chroniques de Louis XII, che, pur essendo poco nota, rappresenta un documento fondamentale per comprendere il periodo a cavallo fra Quattro e Cinquecento in Francia. Cortigiano, letterato ed ecclesiastico, Jean d'Auton pone al centro della sua ricerca storiografica le guerre d'Italia, analizzate però dal punto di vista del sovrano, Luigi XII. Il presente studio ripercorre le tappe fondamentali dell'opera di Jean d'Auton, soffermandosi, in particolare, sul suo giudizio relativo alla struttura politica e sociale del regno di Francia: i «trois acteurs majeurs, la Noblesse, les bons Français et la Personne royale» costituiscono una gerarchia piramidale, di cui vengono puntualmente analizzate le componenti. L'A., inoltre, dedica ampio spazio alla propaganda messa in atto da Jean d'Auton attraverso le sue Chroniques, propaganda finalizzata a giustificare le guerre d'Italia e l'espansione francese e inserita in una ricca tradizione di opere celebrative del sovrano. Infine, viene messa in evidenza una vera e propria «transfiguration eschatologique» operata dallo storico sulla figura del re, che diventa così «le premier des roys chrétiens», legittimato da Dio a possedere molto più del solo regno di Francia. 